\title{
Питання психології
}

УДК 159.923 .2

DOI: $10.33099 / 2617-6858-21-62-4-34-40$

Гриньова Н. В. кандидат психологічних наук, дочент, доцент кафедри психології Уманського державного педагогічного університету імені Павла Тичини https://orcid.org/0000-0001-7261-9871

\section{ПСИХОЛОГІЧНІ МЕХАНІЗМИ СТАНОВЛЕННЯ ПРОФЕСІЙНОЇ СВІДОМОСТІ МАЙБУТНІХ ПСИХОЛОГІВ У ЗАКЛАДІ ВИЩОЇ ОСВІТИ}

У статті розкриваються психологічні механізми становлення професійної свідомості майбутніх психологів у закладі вищої освіти, якими можна вважати професійну установку, професійну адаптацію, професійну рефлексію, иілепокладання і професійну самооиінку.

Ключові слова: психологічні механізми; професійна свідомість; майбутні психологи; заклад вищоі освіти; професійна установка; професійна адаптація; професійна рефлексія; иілепокладання; професійна самооиінка.

Вступ. Аналіз наукової літератури свідчить про необхідність більш глибокого проникнення у природу психічного i недостатню розробку проблеми психологічних механізмів, що $є$ в основі становлення i розвитку професійної свідомості. Не зважаючи на різноманітність підходів до цього феномену і безлічі його трактувань, під «механізмом» дослідники розуміють докладне розкриття сутності явища. «Розкрити механізм чого-небудь, зазначає Є.I. Бойко, - це значить проникнути в його внутрішній устрій (будова), усвідомити взаємозв'язок і взаємозалежність частин або елементів цілого і через це зрозуміти i пояснити сутність предмета (процесу), його необхідний закономірний перебіг і його неминуче виникнення з тих чи інших умов» [5, с. 448]. На думку Б.С. Братуся, предметом психологічного дослідження слід зробити не готові, сформовані властивості особистості, а механізми їхнього формування, становлення [6]. На думку А.В. Брушлинського, історичний підхід до психіки людини повинен «визначати конкретну трактування самих «механізмів» розумової і взагалі психічної діяльності [7, с. 93].

Проведені дослідження не повною мірою розкривають психологічну сутність механізмів професійної свідомості майбутнього психолога, не відображають особливості їхньої внутрішньої роботи в процесі професійної освіти. У той же час ефективність професійної діяльності психолога, у тому числі і майбутнього, обумовлена ступенем сформованості професійної свідомості, розвиток якої, у свою чергу, залежить від сформованості і збалансованості його механізмів та ефективності їхньої актуалізації.

Мета дослідження. Обгрунтувати i визначити провідні психологічні механізми становлення професійної свідомості майбутніх психологів у закладі вищої освіти.

\section{Теоретичне підгрунтя.}

У психологічній літературі поняття «механізм» зустрічається достатньо часто і найчастіше як синонім понять «спосіб», «метод» [11]. Зовсім інше значення термін «механізм» отримує у Б.М. Теплова [17]. Характеризуючи вимогу об'єктивного методу у психології, він стверджує, що для наукового пояснення психічних процесів необхідно вивчати нервові механізми процесу відображення. Л.І. Анциферова пов'язує вивчення психологічних механізмів 3 дослідженням динаміки психічного життя. На іiі думку, психологічні механізми - це ті, що закріпилися у психологічній організації особистості функціональні можливості реалізації іiі психічного життя, в результаті чого змінюється режим іiі функціонування. «Психологічні механізми виступають як способи перетворення, організації особистості лише тому, що вони $\epsilon$ 


\section{Питання психології}

механізмами реальних або уявних перетворень, взаємовідносин індивіда 3 суспільством, зі світом у цілому» $[3$, с. 8$]$.

Достатньо інтенсивно проблема психологічних механізмів розробляється у соціальній психології та психології особистості. Так, В.С. Мухіна підкреслює роль соціальних детермінант у виникненні психічного механізму цілісної людини, який, на думку авторки, «являє собою систему реакцій $\mathrm{i}$ процесів, дій, що складаються $\mathrm{i}$ перетворюються, станів і структури особистості» $[13$, с. 83$]$.

На думку Р.Д. Санжаевої, психологічний механізм - це суб'єктивний опис або відображення на суб'єктивному рівні тих об'єктивних процесів або явищ, які забезпечують взаємодію людини 3 навколишнім середовищем [15]. 3 чого слідує, що психологічний механізм здатний управляти різними енергетичними рівнями взаємодії людини із навколишнім середовищем.

Л.М. Антілогова, що досліджувала психологічні механізми моральної свідомості особистості, визначає механізм як закономірний зв'язок чинників, умов, засобів, продуктивно впливають на розвиток моральної свідомості особистості [2]. Певний інтерес представляє точка зору В.С. Агєєва, який, називаючи як психологічні механізми сприйняття ідентифікацію, емпатію, децентрацію, підкреслює, що, «по-перше, кожен механізм є якісно специфічним, тобто залучається для пояснення строго певних характеристик або закономірностей соціального сприйняття. По-друге, він володіє неоднаковим потенціалом не лише в якісному, але і у кількісному відношенні» $[1$, c. 53-67].

Таким чином, теоретичний аналіз переконує у тому, що психологічний механізм являє собою складноорганізоване утворення, що має завжди внутрішній характер, на відміну від чинників. Будучи складним психологічним утворенням, механізм містить різні за своєю природою складові. Питання про те, якою $є$ їхня природа, викликає на сьогоднішній день багато різних відповідей. Механізм функціонує у взаємозв'язку 3 іншими механізмами, специфічно проявляючи себе на різних етапах становлення та розвитку суб'єкта діяльності. При цьому дія конкретного механізму залежить від реалізації інших, отже, можна говорити про «ланцюжку» включених один в одного взаємопов'язаних механізмів. Усі механізми $\epsilon$ неоднорідними, їм властива узагальненість i різна ступінь конкретизації. Деякі 3 них мають статус загального механізму, оскільки їхня дія проглядається у переважній більшості випадків поведінки i діяльності індивіда. Саме система механізмів, а не один єдиний механізм, здатна впливати на розвиток свідомості суб'єкта діяльності.

Так, Л.М. Мітіна під механізмом розуміє сукупність внутрішніх логічних зв'язків, процедур, що визначають виникнення змін у поведінці фахівця, який саморозвивається [12, с. 113]. Психологічним механізмом саморозвитку, на думку авторки, $є$ внутрішня активність особистості, активність 3 перетворення власного внутрішнього світу.

О.А. Гульбс, Н.І. Пов'якель, Н.Ф. Шевченко називають психологічних механізми, які, на їхню думку, впливають на розвиток професійної свідомості фахівця. Це механізм рефлексії, який розуміється автором як здатність до самовизначення, i механізм визначення мети - як спосіб зв'язування цінностей і засобів у професійній діяльності $[8 ; 14 ; 19]$. Н.В. Чепєлєва як умову розвитку професійної компетентності фахівця розглядає взаємодію механізмів стереотипізації і рефлексії [18].

Г.О. Балл і П.С. Перепелиця стверджують, що готовність майбутнього фахівця до виконання професійної діяльності визначається рівнем сформованості професійної установки у структурі його особистості [4]. Н.Ф. Шевченко показано, що у формуванні професійної спрямованості особистості майбутнього психолога важливу роль відіграє професійна самооцінка [20]. Особливо великий вплив вона справляє на формування таких компонентів професійної спрямованості, як суб'єктивна позиція 


\section{Питання психології}

психолога, ставлення до себе як психолога. О.М. Кокуном висвітлено роль професійної адаптації як механізму, який спонукає особистість до саморозкриття, гармонізації взаємин з навколишнім середовищем [10].

Методи дослідження. Теоретичний аналіз, синтез, узагальнення, порівняння. Психологічнй механізм як складноорганізоване утворення являє собою сукупність внутрішніх психічних перетворень, що виявляються у структурних змінах професійної свідомості, відносинах i зв'язках іiі структурних компонентів, який, взаємодіючи $з$ психологічними чинниками та умовами, оптимізує процес становлення професійної свідомості майбутнього психолога. Пошук ефективних заходів збільшення результативності психологічних механізмів грунтується на осягненні їхньої змістовної сутності.

Проведений аналіз переконує, що психологічні механізми оптимізують процес становлення професійної свідомості психолога. Психологічні механізми, поперше, не іманентно притаманні професійній свідомості психолога, а розвиваються в процесі освоєння професійної діяльності 3 врахуванням індивідуально-типологічних особливостей особистості i соціальних чинників життєдіяльності; по-друге, кожен механізм є якісно специфічним, тобто має змістовні і динамічні характеристики; потретє, психологічний механізм як явище психіки, являє собою таку інтегративну психічну реальність, якісна визначеність якої полягає у тому, що він може одночасно проявлятися психічним процесом, психічним властивістю і психічним станом [9].

\section{Результати і обговорення.}

Сутність психологічного механізму професійної свідомості полягає у тому, що він як особлива специфічна діяльність забезпечує перегрупування елементів свідомості і перетворення структури діючих зв'язків, цілісність професійної свідомості, вдосконалення і становлення його в процесі освоєння професійної діяльності [8]. Структурна перебудова та гармонізація компонентів професійної свідомості майбутнього психолога набувають під час такого перетворення чітко виражену динаміку змін. Показником динаміки $\epsilon$ збільшення i посилення значущих зв'язків між психологічними механізмами i структурними компонентами професійної свідомості, між компонентами когнітивної, афективної і поведінкової складових (сфер) професійної свідомості і між самими механізмами, забезпечуючи на цій основі поступальну прогресивну зміна професійної свідомості у закладі вищої освіти.

Кожен психологічний механізм, що забезпечує становлення професійної свідомості майбутнього психолога, функціонує у взаємозв'язку 3 іншими механізмами, специфічно проявляючи себе на різних етапах професійної підготовки. Найважливішою функцією психологічних механізмів $€$ активізація професійної свідомості майбутнього психолога, спрямованого на досягнення більш високого рівня його розвитку та успішності виконання професійної діяльності.

Психологічними механізмами становлення професійної свідомості майбутнього психолога на основі логікозмістовного аналізу, що виходить 3 єдності особистості i професії, $€$ професійна установка, професійна адаптація, професійна рефлексія, цілепокладання і професійна самооцінка.

Базовим механізмом є професійна установка. Саме установка на професію психолога визначає особливості професійного становлення майбутнього фахівця 3 психологічної спеціальності, ступінь вираженості професійної свідомості. Вона вибірково здатна бути i такою, що спрямовує, і полегшує навчально-професійну діяльність майбутнього психолога, $є$ тією потенційною та актуальною силою, яка забезпечує успішність професійної діяльності. Професійна установка як основоположний механізм становлення i розвитку професійної свідомості майбутнього психолога пов'язана зі усіма виокремленими механізмами i забезпечує оптимальність їхнього функціонування. 


\section{Питання психології}

Професійна рефлексія - це діяльність свідомості в осмисленні професійних цілей, мотивів, установок, зв'язків і відносин, які складаються в процесі діяльності та обумовлених специфікою професії та етапом (курсом) професійної підготовки майбутнього психолога. Завдяки професійній рефлексії майбутній фахівець усвідомлює професійні цілі, завдання та умови здійснення професійної діяльності, зв'язки і відносини, що складаються під час діяльності та обумовлені специфікою професії та етапом професійного розвитку здобувача вищої освіти; усвідомлює особистісний сенс професійної діяльності, що проявляється у мотиваційно-ціннісному відношенні до професії, до себе як психолога, у потребі професійного самовдосконалення, i який визначається у власних можливостях.

Цілепокладання $\epsilon$ специфічною діяльністю свідомості, у межах якої відбувається рефлексія майбутнім психологом власної діяльності, себе як фахівця, постановка нових цілей. Завдяки усвідомленого процесу постановки цілей у майбутнього психолога відбувається розвиток діяльнісної позиції, становлення його суб'єктності, що виражається у регулюванні власної активності, у цілеспрямованості та наполегливості при досягненні мети.

Професійна самооцінка - це діяльність свідомості, яка полягає в оцінці або окремих професійно значущих якостей, дій суб'єкта, або узагальненої оцінки себе як професіонала; сприяє організації та саморегуляції професійної діяльності, поведінки відповідно до прийнятих у професійному співтоваристві норм і цінностей; впливає на динаміку оволодіння професійною майстерністю; коригує ймовірність досягнення мети; стимулює впевненість у собі, професійну задоволеність, успішність професійної адаптації. Актуалізація професійної адаптації сприяє осмисленню і встановленню нових форм міжособистісних відносин, включених у професійну діяльність; спонукає майбутнього психолога до саморозкриття, сприяє становленню активної професійної позиції при вирішенні професійних завдань.

Висновки. Становлення професійної свідомості майбутнього психолога відбувається під впливом низки різного ступеня дієвості психологічних механізмів: професійної установки, професійної рефлексії, цілепокладання, професійної самооцінки, професійної адаптації. Психологічний механізм як складноорганізоване утворення у цілісній структурі професійної свідомості являє собою сукупність внутрішніх психічних перетворень (що виявляються у структурних змінах професійної свідомості, у відносинах і зв'язках ¥іi структурних компонентів) i, взаємодіючи 3 чинниками та умовами, оптимізує процес становлення професійної свідомості майбутнього психолога. Сутність психологічного механізму полягає у тому, що він як особлива специфічна діяльність забезпечує перегрупування елементів професійної свідомості і перетворення структури діючих зв'язків, цілісність професійної свідомості, іiі становлення i вдосконалення в процесі освоєння професійної діяльності. Ефективність впливу психологічних механізмів на процес становлення професійної свідомості майбутнього психолога зростає, коли вони актуалізуються системно.

\section{Список використаних джерел}

1. Агеев В.С. Механизмы социального восприятия. Психологический журнал. 1989. Т.10. №2. С. 53-67.

2. Антилогова Л.Н. Психологические механизмы развития нравственного сознания личности: дис. ... д-ра психол. наук. Новосибирск, 1999. 390 с.

3. Анцыферова Л.И. О динамическом подходе к психологическому изучению личности. Психологический журнал. 1981. Т.2. №2. С. 8-18. 


\section{Питання психології}

4. Балл Г.О., Перепелиця П.С. Формування готовності до професійної праці у контексті гуманізації освіти // Психологічні аспекти гуманізації освіти. Книга для вчителя/ Київ-Рівне, 1996. 148 с.

5. Бойко В.И. Механизмы умственной деятельности. Избранные пси-хологические труды / науч. ред. А.В. Брушлинский и Т.Н. Ушакова. М.: Московский психолого-социальный институт; Воронеж: НПО «МОДЭК», 2002. 688 с.

6. Братусь Б.С. Аномалии личности. М.: Мысль, 1988. 301 с.

7. Брушлинский А.В. Культурно-историческая теория мышления. М.: Высшая школа, 1968. 104 с.

8. Гульбс О.А. Теоретико-методологічні основи категоріальної структури професійної свідомості викладачів вищої школи: дис. ... д-ра психол. наук. Харк. нац. ун-т ім. В.Н. Каразіна. Х., 2013. 389 с.

9. Карпов А.В. Рефлексивность как психическое свойство и методика её диагностики. Психологический журнал. 2003. Т.24. №5. С. 45-57.

10. Кокун О.М. Оптимізація адаптаційних можливостей людини: психофізіологічний аспект забезпечення діяльності: Монографія. К.: Міленіум, 2004. 265 с.

11. Кондратенко Л.О. Поняття про психологічні механізми: історико-теоретичний огляд. Лабораторія сучасних інформаційних технологій навчання Інституту психології імені Г.С. Костюка НАПН України: вебсайт. URL: http://www.newlearning.org.ua/content/12- chervnya-2014rvidbuvsyateoretikometodologichniy-seminar-ponyattyapro-psihologichni (дата звернення 17.12.2019).

12. Митина Л.М. Психология профессионального развития учителя. М.: Флинта: Московский психолого-социальный институг, 1998. 200 с.

13. Мухина В.С. Возрастная психология: учебник для студентов вузов. М., 1997. 430 с.

14. Пов'якель Н.І. Професійна рефлексія психолога-практика. Практична психологія та соиіальна робота. 1998. №6-7. С. 3-6.

15. Санжаева Р.Д. Психологические механизмы формирования готовности человека к деятельности: дис. ... д-ра психол. наук. Новосибирск, 1997. 354 с.

16. Смульсон М.Л. Психологічні механізми в концепції навчання Ю.І. Машбиця. Технології розвитку інтелекту. 2014. T.1. №6. URL: https://core.ac.uk/download/pdf/32307586.pdf (дата звернення: 20.12.2019).

17. Теплов Б.М. Об объективном методе в психологии // Избранные труды: в 2 т. Т. 2. М.: Педагогика, 1985. С. 281-309.

18. Чепелєва Н.В. Становлення професійної компетентності в процесі вузівської підготовки практичних психологів / Психолого-педагогічна наука і суспільна ідеологія: Матеріали методологічного семінару АПН України, 12 листопада 1998 р. К.: Гнозис, 1998. 605 с.

19. Шевченко Н.Ф. Формування професійної свідомості практичних психологів у системі вищої освіти: дис. д-ра психол. н. Харків, 2006. 485 с.

20. Шевченко Н.Ф. Дослідження професійної спрямованості майбутніх психологів. Вісник Дніпропетровського університету імені Альфреда Нобеля. Серія «Педагогіка і психологія». 2013. № 1 (5). C. 95-101.

\section{References}

1. Ageev V.S. (1989) Mehanizmy social'nogo vosprijatija [Mechanisms of social perception]. Psihologicheskij zhurnal. T.10. №2. S. 53-67. (in Russian)

2. Antilogova L.N. (1999) Psihologicheskie mehanizmy razvitija nravstvennogo soznanija lichnosti [Psychological mechanisms of the development of the moral consciousness of the individual]: dis. ... d-ra psihol. nauk. Novosibirsk. 390 s. (in Russian)

3. Ancyferova L.I. (1981) O dinamicheskom podhode k psihologicheskomu izucheniju lichnosti [About the dynamic approach to the psychological study of personality]. Psihologicheskij zhurnal. T.2. №2. S. 8-18. (in Russian)

4. Ball G.O., Perepelycja P.S. (1996) Formuvannja gotovnosti do profesijnoi' praci u konteksti gumanizacii' osvity [Formation of readiness for professional work in the context of humanization of education] // Psyhologichni aspekty gumanizacii' osvity. Knyga dlja vchytelja/ Kyi'v-Rivne. 148 s. (in Ukranian)

5. Bojko V.I. (2002) Mehanizmy umstvennoj dejatel'nosti [Mechanisms of mental activity]. Izbrannye psihologicheskie trudy / nauch. red. A.V. Brushlinskij i T.N. Ushakova. M.: Moskovskij psihologo-social'nyj institut; Voronezh: NPO «MODJeK». 688 s. (in Russian) 


\section{Питання психології}

6. Bratus' B.S. (1988) Anomalii lichnosti [Personality anomalies]. M.: Mysl'. 301 s. (in Russian)

7. Brushlinskij A.V. (1968) Kul'turno-istoricheskaja teorija myshlenija [Cultural-historical theory of thinking]. M.: Vysshaja shkola. 104 s. (in Russian)

8. Gul'bs O.A. (2013) Teoretyko-metodologichni osnovy kategorial'noi' struktury profesijnoi' svidomosti vykladachiv vyshhoi' shkoly [Theoretical and methodological bases of categorical structure of professional consciousness of higher school teachers]: dys. ... d-ra psyhol. nauk. Hark. nac. un-t im. V.N. Karazina. H., 2013. 389 s. (in Ukranian)

9. Karpov A.V. (2003) Refleksivnost' kak psihicheskoe svojstvo i metodika ejo diagnostiki [Reflexivity as a mental property and a method for its diagnosis]. Psihologicheskij zhurnal. T.24. №5. S. 45-57. (in Russian)

10. Kokun O.M. (2004) Optymizacija adaptacijnyh mozhlyvostej ljudyny: psyhofiziologichnyj aspekt zabezpechennja dijal'nosti [Optimization of human adaptive capabilities: psychophysiological aspect of activity support]: Monografija. K.: Milenium. 265 s. (in Ukranian)

11. Kondratenko L.O. (2014) Ponjattja pro psyhologichni mehanizmy: istoryko-teoretychnyj ogljad [The concept of psychological mechanisms: a historical and theoretical review]. Laboratorija suchasnyh informacijnyh tehnologij navchannja Instytutu psyhologii' imeni G.S. Kostjuka NAPN Ukrai'ny: vebsajt. URL: http://www.newlearning.org.ua/content/12- chervnya-2014r-vidbuvsyateoretikometodologichniy-seminarponyattyapro-psihologichni (data zvernennja 17.12.2019). (in Ukranian)

12. Mitina L.M. (1998) Psihologija professional'nogo razvitija uchitelja [Psychology of teacher professional development]. M.: Flinta: Moskovskij psihologo-social'nyj institut. 200 s. (in Russian)

13. Muhina V.S. (1997) Vozrastnaja psihologija [Age-related psychology]: uchebnik dlja studentov vuzov. M. 430 s. (in Russian)

14. Pov'jakel' N.I. (1998) Profesijna refleksija psyhologa-praktyka [Professional reflection of a psychologist-practitioner]. Praktychna psyhologija ta social'na robota. №6-7. S. 3-6. (in Ukranian)

15. Sanzhaeva R.D. (1997) Psihologicheskie mehanizmy formirovanija gotovnosti cheloveka k dejatel'nosti [Psychological mechanisms of formation of a person's readiness for activity]: dis. ... d-ra psihol. nauk. Novosibirsk. 354 s. (in Russian)

16. Smul'son M.L. (2014) Psyhologichni mehanizmy v koncepcii' navchannja Ju.I. Mashbycja [Psychological mechanisms in the concept of learning Yu.I. Mashbitsya]. Tehnologii' rozvytku intelektu. T.1. №6. URL: https://core.ac.uk/download/pdf/32307586.pdf (data zvernennja: 20.12.2019). (in Ukranian)

17. Teplov B.M. (1985) Ob ob\#ektivnom metode $\mathrm{v}$ psihologii [On the objective method in psychology] // Izbrannye trudy: v 2 t. T. 2. M.: Pedagogika. S. 281-309. (in Russian)

18. Chepeljeva N.V. (1998) Stanovlennja profesijnoi' kompetentnosti v procesi vuzivs'koi' pidgotovky praktychnyh psyhologiv [Formation of professional competence in the process of university training of practical psychologists] / Psyhologo-pedagogichna nauka i suspil'na ideologija: Materialy metodologichnogo seminaru APN Ukrai'ny, 12 lystopada 1998 r. K.: Gnozys. 605 s. (in Ukranian)

19. Shevchenko N.F. (2006) Formuvannja profesijnoi' svidomosti praktychnyh psyhologiv u systemi vyshhoi' osvity [Formation of professional consciousness of practical psychologists in the system of higher education]: dys. d-ra psyhol. n. Harkiv. 485 s. (in Ukranian)

20. Shevchenko N.F. (2013) Doslidzhennja profesijnoi' sprjamovanosti majbutnih psyhologiv [Research of professional orientation of future psychologists]. Visnyk Dnipropetrovs'kogo universytetu imeni Al'freda Nobelja. Serija «Pedagogika i psyhologija». № 1 (5). S. 95-101. (in Ukranian)

\section{Резюме}

Гринева Н. В. кандидат психологических наук, доцент, доиент кафедры психологии Уманского государственного педагогического университета имени Павла Тычины

\section{ПСИХОЛОГИЧЕСКИЕ МЕХАНИЗМЫ СТАНОВЛЕНИЯ ПРОФЕССИОНАЛЬНОГО СОЗНАНИЯ БУДУЩИХ ПСИХОЛОГОВ В УЧРЕЖДЕНИИ ВЫСШЕГО ОБРАЗОВАНИЯ}

В статье раскрываются психологические механизмы становления профессионального сознания будущих психологов в учреждении высшего образования, которыми можно считать профессиональную установку, профессиональную адаптаџию, профессиональную рефлексию, иелеполагание $u$ профессиональную самооценку. 


\section{Питання психології}

Ключевые слова: психологические механизмы; профессиональное сознание; будущие психологи; учреждение высшего образования; профессиональная установка; профессиональная адаптация; профессиональная рефлексия; иелеполагание; профессиональная самооценка.

\section{Summary \\ Grynyova N. V. Uman state pedagogical university named after Pavlo Tychyna \\ PSYCHOLOGICAL MECHANISMS OF FORMATION OF PROFESSIONAL CONSCIOUSNESS OF FUTURE PSYCHOLOGISTS IN HIGHER EDUCATION INSTITUTION}

Introduction. The conducted researches do not fully reveal the psychological essence of the mechanisms of professional consciousness of the future psychologist, do not reflect the peculiarities of their internal work in the process of professional education. At the same time, the effectiveness of the psychologist's professional activity, including the future, is due to the degree of formation of professional consciousness, the development of which, in turn, depends on the formation and balance of its mechanisms and the effectiveness of their actualization.

Purpose. To substantiate and determine the leading psychological mechanisms of formation of professional consciousness of future psychologists in higher education.

Methods. Theoretical analysis, synthesis, comparison, generalization.

Originality. The psychological mechanism is a complex organization, which is always internal, in contrast to the factors. Being a complex psychological formation, the mechanism contains components of different nature. The question of what their nature is raises many different answers today. The mechanism functions in conjunction with other mechanisms, specifically manifesting itself at different stages of formation and development of the subject of activity. The action of a particular mechanism depends on the implementation of others, therefore, we can talk about a "chain" of interconnected mechanisms. All mechanisms are heterogeneous, they are characterized by generalization and varying degrees of concretization. Some of them have the status of a general mechanism, as their action is seen in the vast majority of cases of behavior and activities of the individual. It is a system of mechanisms, not a single mechanism, that can influence the development of consciousness of the subject of activity.

Conclusion. The formation of professional consciousness of the future psychologist is under the influence of a number of different degrees of effectiveness of psychological mechanisms: professional attitude, professional reflection, goal setting, professional self-esteem, professional adaptation. Psychological mechanism as a complex formation in the holistic structure of professional consciousness is a set of internal mental transformations (manifested in structural changes in professional consciousness, in the relationships and connections of its structural components) and, interacting with factors and conditions, optimizes the formation of professional consciousness of the future psychologist.

Keywords: psychological mechanisms; professional consciousness; future psychologists; higher education institution; professional installation; professional adaptation; professional reflection; goal setting; professional self-esteem.

Recelved/Поступила: 16.09.21. 